\title{
FUNCTIONAL STOLARSKY MEANS
}

\author{
C. E. M. PeArCe, J. PeČARić AND V. ŠIMIĆ
}

Abstract. A functional generalization is given for Stolarsky mean and its basic properties investigated. Functional means in $n$ variables are also considered.

Mathematics subject classification (1991): 26B25, 26D15.

Key words and phrases: Stolarsky mean, functional means, convexity, Hadamard's inequality.

\section{REFERENCES}

[1] P. S. Bullen, D. S. Mitrinović And P. M. Vasić, Means and their inequalities, Reidel, Dordrecht, 1988.

[2] S.-Y. Chung, Functional means and harmonic functional means, Bull. Austral. Math. Soc. 57 (1998), 207-220.

[3] A. M. Fink, Two inequalities, Univ. Beograd Publ. Elektrotehn. Fak. Ser. Mat. 6 (1995), 48-49.

[4] A. M. FINK, Hadamard inequalities for logarithmic concave functions, Math. Comput. Modeling (to appear).

[5] P. M. Gill, C. E. M. Pearce And J. PeČArIĆ, Hadamard's inequality for $r$-convex functions, J. Math Anal. Appl. 215 (1997), 461-470.

[6] G. H. Hardy, J. E. Littlewood and G. Pólya, Inequalities, 2nd ed., Cambridge Univ. Press, Cambridge, 1959.

[7] E. Leach And M. Sholander, Extended mean values II, J. Math. Anal. Appl. 92 (1983), 207-223.

[8] B. Mond AND J. PeČARIĆ, A companion to Fink's inequality, Octogon Math. Magazine (Brasor) 5 (1997), 3-8.

[9] E. Neuman, The weighted logarithmic mean, J. Math. Anal. Appl. 188 (1994), 885-900.

[10] Zs. PÁLES, Inequalities for differences of powers, J. Math. Anal. Applic. 131 (1988), 271-281.

[11] Zs. PÁLES, Comparison of two variable homogeneous means, General Inequalities (Oberwolfach 1990), Ed. E. Walter, Birkhäuser Verlag, Basel, 6 (1992), 59-70.

[12] C. E. M. PEARCE AND J. PeČARIĆ, A continuous analogue and an extension of Radó's formula, Bull. Austral. Math. Soc. 53 (1996), 229-233.

[13] C. E. M. PeArce, J. PeČAriĆ And V. Šimić, Stolarsky means and Hadamard's Inequality, J. Math. Anal. Appl. 220 (1998), 99-109.

[14] J. PEČARIĆ AND V. ČULJAK, On Hadamard inequalities for logarithmic convex functions, submitted.

[15] J. PEČARIĆ AND V. ŠIMIĆ, The Stolarsky-Tobey mean in $n$ variables, Math.Inequal.Appl. 2 (1999), $325-341$.

[16] A. O. Pittenger, The logarithmic mean in $n$ variables, Amer. Math. Monthly 92 (1987), 282-291.

[17] F. SAIDI AND R. YounIS, Hadamard and Fejer-type Inequalities, to appear in Archiv der Mathematik.

[18] K. B. StolarsKY, Generalizations of the logarithmic mean, Math. Mag. 48 (1975), 87-92.

[19] M. D. TobeY, A two-parameter homogeneous mean value, Proc. Amer. Math. Soc. 18 (1967), 9-14. 